\title{
Variability of lodine Content in Common Commercially Available Edible Seaweeds
}

\author{
Jane Teas, ${ }^{1}$ Sam Pino, ${ }^{2,3}$ Alan Critchley, ${ }^{4}$ and Lewis E. Braverman ${ }^{3}$
}

Dietary seaweeds, common in Asia and in Asian restaurants, have become established as part of popular international cuisine. To understand the possibility for iodine-induced thyroid dysfunction better, we collected samples of the most common dietary seaweeds available from commercial sources in the United States, as well as harvester-provided samples from Canada, Tasmania, and Namibia. Altogether, 12 different species of seaweeds were analyzed for iodine content, and found to range from $16 \mu \mathrm{g} / \mathrm{g}( \pm 2)$ in nori (Porphyra tenera) to over $8165 \pm 373 \mu \mathrm{g} / \mathrm{g}$ in one sample of processed kelp granules (a salt substitute) made from Laminaria digitata. We explored variation in preharvest conditions in a small study of two Namibian kelps (Laminaria pallida and Ecklonia maxima), and found that iodine content was lowest in sun-bleached blades (514 $\pm 42 \mu \mathrm{g} / \mathrm{g}$ ), and highest amount in freshly cut juvenile blades $(6571 \pm 715 \mu \mathrm{g} / \mathrm{g})$. Iodine is water-soluble in cooking and may vaporize in humid storage conditions, making average iodine content of prepared foods difficult to estimate. It is possible some Asian seaweed dishes may exceed the tolerable upper iodine intake level of $1100 \mu \mathrm{g} / \mathrm{d}$.

\section{Introduction}

I

ODINE WAS FIRST IDENTIFIED as an element based on the observations of Courtois in 1811 that sulfuric acid-treated seaweed ash produced a purple vapor that condensed into purple crystals (1). For many decades, seaweeds were the primary source of iodine for medicinal purposes, only being supplanted by the discovery that iodine could be extracted from silver and saltpeter mining deposits. These mineral sources were less expensive than collecting seaweed and burning it, and by the late 1930s, seaweed was no longer used as an iodine source (2). In the United States, seaweeds have also been used to enrich soil, as sources of inexpensive minerals for animal food supplements, and recently, as food and a natural source of iodine and other minerals in health supplements.

In an earlier study, we and others reported that dietary seaweed delayed the time to tumor onset in a rat dimethylbenzanthracene mammary-induced cancer model (3-7). In preparation for a clinical study in humans, it was necessary to evaluate common edible seaweeds for iodine content since excess iodine intake might adversely affect thyroid function. We present our findings for 12 different edible seaweeds, and evaluate factors that modulate seaweed iodine content.

Seaweeds have been a part of the world's ecosphere for 2 billion years (8), during which time they have changed lit- tle. Although archaeological evidence for the use of seaweeds is hampered by its easily degradable nature, it is likely that seaweeds have been part of traditional diets of coastal dwelling peoples worldwide. Seaweeds have been used by humans as medicine and food for at least 13,000 years. Based on discoveries of seaweeds found at Monte Verde, a late Pleistocene settlement in Chile $(9,10)$ and archeological inference from ancient sites of the Jomon period in Japan (11), seaweeds have been included in three of the major medical traditions: Ayurvedic medicine from the fourth century $\mathrm{BC}$ (12); Traditional Chinese Medicine, with its first reference to its medicinal qualities reportedly made by Shen-nung in the Chinese Materia Medica of 2700 вс (13); and in the Ebers Papyrus, the Egyptian treatise on medical care, written approximately in 1550 вс (14). The medicinal uses of seaweed are vast and range from topical burn therapy to goiter therapy to softening of tumors (15). As food, seaweeds have been treasured by the nobility of Japan and China, as well as commoners such as fishermen living along the coast. In 600 BC, Sze Teu wrote, "Some algae are a delicacy fit for the most honored guests, even for the King himself (11)." Tax records from the eighth century indicate that more than 30 kinds of seaweed were listed as tax payments to the Japanese government (11). National Seaweed Day (February 6) in Japan commemorates this official recognition of the value of seaweed (16), and the continuing high status of seaweed in

\footnotetext{
${ }^{1}$ Department of Health Promotion Education and Behavior, Norman J. Arnold School of Public Health, University of South Carolina and the South Carolina Cancer Center, Columbia, South Carolina.

${ }^{2}$ Iodine Research Laboratory, ${ }^{3}$ Section of Endocrinology, Diabetes and Nutrition, Department of Medicine, Boston University School of Medicine, Boston, Massachusetts.

${ }^{4}$ Process Development, Degussa Food Ingredients, Business Line Degussa Texturant Systems, Baupte, France.
} 
Table 1. Iodine Content of Commercially Available Edible Seaweeds

\begin{tabular}{|c|c|c|c|c|c|c|}
\hline Genus and species & Common name & $\begin{array}{l}\text { Harvest } \\
\text { location }\end{array}$ & Form & $\mathrm{n}$ & $\begin{array}{l}\text { Total iodine } \\
(\mu \mathrm{g} / \mathrm{g})\end{array}$ & $S D$ \\
\hline & American & & & & & \\
\hline \multirow[t]{2}{*}{ Alaria esculenta } & wakame & Maine & Whole & 7 & 110 & 30 \\
\hline & & Maine & Whole & 5 & 431 & 104 \\
\hline Ascophyllum nodosum & Knotted wrack & Maine & Whole & 3 & 646 & 392 \\
\hline Ecklonia maxima & Paddle weed & Namibia & Whole & 6 & 2123 & 352 \\
\hline Eisenia bicyclis & Arame & Japan & Whole & 3 & 586 & 56 \\
\hline Fucus vesiculosis & Bladderwrack & Maine & Whole & 3 & 276 & 82 \\
\hline Hizikia fusiforme & Hijiki & Japan & Whole & 6 & 629 & 153 \\
\hline \multirow[t]{12}{*}{ Laminaria } & Kelp & & & & & \\
\hline & Oarweed & & & & & \\
\hline & (L. longicruis) & Maine & Whole & 3 & 746 & 26 \\
\hline & $\mathrm{Kelp}^{\mathrm{b}}$ & British Columbia Canada & Capsule & 5 & 1259 & 200 \\
\hline & $K_{o m b u}{ }^{b}$ & Washington & Whole & 7 & 1350 & 362 \\
\hline & Wild kelp ${ }^{b}$ & Maine & Capsule & 7 & 1356 & 665 \\
\hline & $\mathrm{Kelp}^{\mathrm{b}}$ & British Columbia Canada & Whole & 5 & 1513 & 117 \\
\hline & Oarweed & Maine & Whole & 6 & 1862 & 520 \\
\hline & $\begin{array}{l}\text { Fingered tangle } \\
(\text { L. digitata }) \\
\text { Mitsuishi-kombu }\end{array}$ & Maine & Whole & 6 & 1997 & 563 \\
\hline & (L. angustata) & Japan & Powdered & 4 & 2353 & 65 \\
\hline & Fingered tangle & Maine & Whole & 6 & 2984 & 910 \\
\hline & Fingered tangle & Iceland & Granules & 6 & 8165 & 373 \\
\hline Palmaria palmata & Dulse & Maine & Whole & 3 & 72 & 23 \\
\hline Porphyra tenera & Nori, purple laver & Japan & Sheet & 3 & 16 & 2 \\
\hline Postelsia palmaeformis & Sea palm & California & Whole & 7 & 871 & 231 \\
\hline Sargassum & Horsetail tangle, & Washington & Whole & 5 & 30 & 1 \\
\hline \multirow[t]{6}{*}{ Undaria pinnatifida } & $\begin{array}{l}\text { Mekabu (Undaria } \\
\text { spore) }\end{array}$ & Tasmania & Tablets & 4 & 22 & 1 \\
\hline & Wakame & Tasmania & Powder & 5 & 32 & 4 \\
\hline & Wakame & Tasmania & Whole & 4 & 41 & 14 \\
\hline & Wakame & Japan & Whole & 6 & 42 & 17 \\
\hline & Mekabu & Tasmania & Powder & 5 & 53 & 3 \\
\hline & Wakame & New Zealand & Whole & 6 & 115 & 42 \\
\hline
\end{tabular}

aCommon names according to Madlener (42) and Arasaki and Arasaki (11).

${ }^{b}$ No species indicated.

Japanese culture. In a recent article on improving public health nutrition in Japan, a recommendation for increasing seaweed consumption was included (17).

The actual amount of seaweed consumed is difficult to quantify because it is often as flavoring to noodles, soups, garnishes, and added as part of mixed vegetable dishes, as well as being a food that is served as a distinct entity as a snack, salad or side dish. In addition, seaweed is a part of military and religious ceremonial celebration foods in Japan. Soups containing seaweed (miso or wakame) have traditionally been included as part of most meals in Japan (8), although this is changing toward more Western foods (18). Estimated iodine intake of people in Japan, mostly from seaweed, ranges from 200 to $20,000 \mu \mathrm{g} / \mathrm{d}$, with the average estimate of 500-1000 $\mu \mathrm{g} / \mathrm{d}$ (19). The average seaweed intake in Japan is approximately $4-7 \mathrm{~g} / \mathrm{d}(11,20,21)$. Commercial data on seaweed sales in Japan estimate that the national average seaweed consumption per person is $4 \mathrm{~kg} / \mathrm{yr}$, or closer to $10 \mathrm{~g}$ per person per day (22).

In Japan, 21 species of seaweed are routinely included in the diet and in Korea more than 40 kinds of seaweed are commonly used as food (11). Elsewhere in the Pacific basin, in Hawaii and other Polynesian islands, 29 kinds of seaweed have been reported as food, medicine, and as part of religious celebrations in precolonial times $(23,24)$, and seaweeds are still part of the diets of many indigenous people living in Asia, Polynesia and the Pacific Islands.

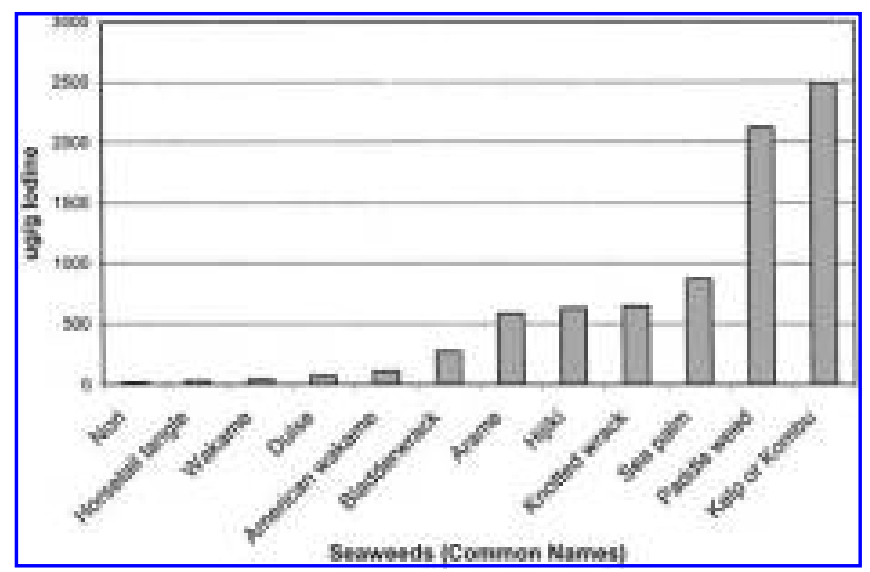

FIG. 1. Iodine content of dietary seaweeds compared by species. 


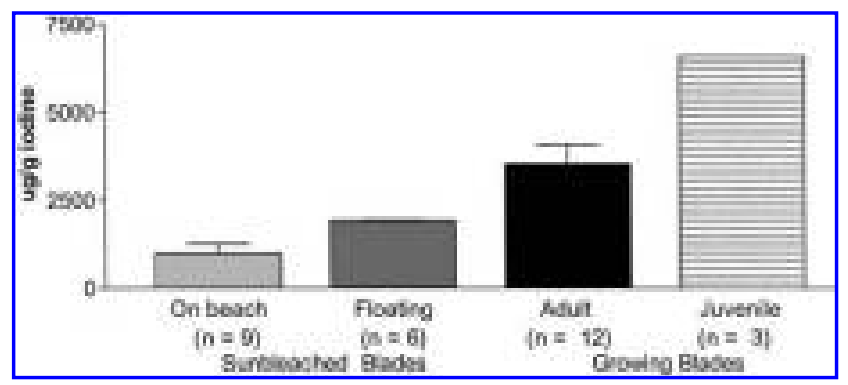

FIG. 2. Iodine content of Laminaria pallida compared by harvesting condition and age of seaweed sample.

Seaweeds are increasingly common foods and food supplements in the United States. As international foods have become commonplace throughout the world, seaweed consumption has increased. One study of marketing trends reported that $15 \%$ of Americans enjoy Japanese cooking (25). Popular claims for seaweed are that they provide an all-natural source of minerals. Such claims of efficacy have placed seaweeds in the role of nutriceuticals as well as regular food.

\section{Methods and Materials}

We obtained seaweed samples from health food stores in central Massachusetts, by contacting seaweed harvesters in Tasmania, Maine, and British Columbia, and collecting samples of kelp (Laminaria and Ecklonia) of known age and condition from Namibia. All samples were in the form that an average consumer might buy.

Samples were analyzed according to the standard determination of total iodine as outlined by Benotti et al. (26). This uses the reduction-oxidation reaction between ceric and arsenite catalyzed by iodide. The iodine concentration is proportional to its catalytic activity. Twenty-five 50-mg samples were digested with chloric acid and diluted with iodine free deionized water. They were then measured spectrometrically at $420 \mathrm{~nm}$ with a Technicon Autoanalyzer (Technicon Instrument, Inc, Tarrytown, NY). Values in the seaweed were based on an iodine standard curve. At least three aliquots from each seaweed were analyzed for iodine content. The mean value is presented \pm standard deviation (SD).

\section{Results}

Iodine content of seaweeds varied from $16 \mu \mathrm{g} / \mathrm{g}$ to 8165 $\mu \mathrm{g} / \mathrm{g}$ (Table 1). The highest iodine-containing sample came from kelp granules that had been made from Laminaria digitata harvested off the coast of Iceland. The kelp granules were made of dried and pulverized seaweed.

In Figure 1 we compare the common edible seaweeds by iodine content. It is interesting to note that American wakame (Alaria) and kelp (Laminaria), both remarkably similar in appearance, have a marked difference in iodine content, even when both specimens were harvested on the same day by the same harvester from the same bay.

Iodine has been reported to vary with age and condition of the plant, with iodine loss thought to occur rapidly once a seaweed is no longer growing. In Figure 2, sun-bleached seaweed collected from the beach had the lowest iodine content, followed by samples collected from floating drifts of seaweed. Samples cut from growing juvenile $(<50 \mathrm{~cm})$, had approximately twice the amount of iodine per gram as found in samples from adult seaweed.

Figure 3 presents the iodine content in different parts of two kinds of seaweed (Ecklonia maxima and Laminaria pallida). The iodine content in the inedible stipes was approximately $50 \%$ lower than the blades. Meristematic tissue, the growing area at the base of the blade of the seaweed, was available for Laminaria from Namibia. The higher concentration of iodine in this area of the seaweed suggests that iodine is important to rapidly dividing seaweed cells.

\section{Discussion}

Dietary seaweeds have great variability in iodine content. The problem is further compounded by the use of some high-iodine seaweeds as flavoring in some traditional Asian soup stocks and other dishes, in which the seaweed is removed before serving. A range of post harvest factors affects iodine content of seaweed, including preparation and storage conditions.

The iodine in common edible seaweeds is mostly water soluble, with highest levels reported in kelp (Laminaria), of which $99.2 \%$ is water soluble (27), although another edible seaweed, Sargassum, had only $40 \%$ water soluble iodine. The bioavailability of the seaweed iodine to humans has been reported (28-30). Hou et al. (27) reported that the chemical species of iodine in common seaweeds were primarily $\mathrm{I}^{-}$, $66 \%$ (Sargassum) to $88 \%$ in kelp (Laminaria). Organic iodine ranged from $10 \%$ in kelp to $29 \%$ in Sargassum, and iodate $\left(\mathrm{IO}_{3}{ }^{-}\right.$) from $1.4 \%$ in kelp to $4.5 \%$ in Sargassum (27).

Geographic variation in iodine content is also a factor, and iodine values for seaweeds from our study and other published work is presented in Table 2. For example, iodine in wakame (Undaria) was 23 times higher in the sample from China, and 2.5 times higher in the samples analyzed by Lee et al. (31) than in the samples we analyzed from New Zealand, Australia, and Japan. Kelp varied from an average of $1542 \mu \mathrm{g} / \mathrm{g}$ in the 10 species of Laminaria in our study to $5307 \mu \mathrm{g} / \mathrm{g}$ in the values reported for French Laminaria (30). The red seaweeds (Rhodophyta) analyzed (dulse and nori) were consistently lower in iodine, less than $100 \mu \mathrm{g} / \mathrm{g}$.

In studies of iodine loss caused by storage conditions, Marchal et al. (29) reported that iodine content remained more or less constant when stored in watertight bags or boxes, but lost almost half of its iodine content in the first 40 days when stored in open containers or in paper bags, especially under

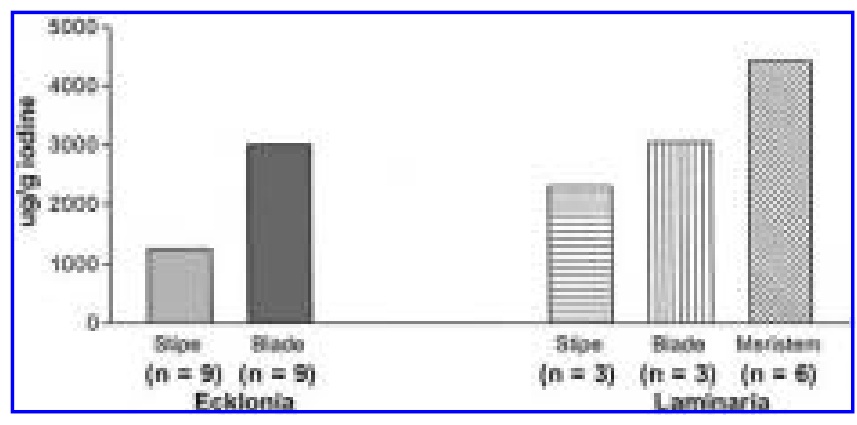

FIG. 3. Iodine content compared by part of adult fresh seaweed. 
Table 2. Comparison of Seaweed Iodine by Genus, Geographic Location, and Study

\begin{tabular}{|c|c|c|c|c|c|}
\hline & $\begin{array}{c}\text { This study } \\
\mu \mathrm{g} / \mathrm{g}\end{array}$ & $\begin{array}{l}\text { Lee et al. } \\
(31) \\
\mu g / g\end{array}$ & $\begin{array}{c}\text { Hou and Yan } \\
(43) \\
\mu g / g\end{array}$ & $\begin{array}{c}\text { Aquaron et al. } \\
(30) \\
\mu g / g\end{array}$ & $\begin{array}{c}\text { Van Netten et al. } \\
(44) \\
\mu g / g\end{array}$ \\
\hline Seaweed origin & $\begin{array}{c}\text { U.S., Canada, } \\
\text { Namibia, } \\
\text { Tasmania, } \\
\text { Japan }\end{array}$ & UK & China & France & British Columbia \\
\hline Arame & 586 & $714^{\mathrm{a}}$ & & & 600 \\
\hline $\begin{array}{l}\text { Dulse } \\
\text { Hijiki }\end{array}$ & $\begin{array}{r}72 \\
629\end{array}$ & $\begin{array}{r}44 \\
391\end{array}$ & & & 436 \\
\hline $\begin{array}{l}\text { Kelp granules. } \\
\text { tablets (salt } \\
\text { substitute) }\end{array}$ & 8165 & 67 & & & 815 \\
\hline Kelp/kombu & $1542^{\mathrm{b}}$ & 2650 & 3040 & 5307 & 2110 \\
\hline Nori & 16 & 43 & 36 & & $\begin{array}{r}17 \\
185\end{array}$ \\
\hline Wakame & $66^{c}$ & $161^{a}$ & 1571 & & $\begin{array}{r}60 \\
102\end{array}$ \\
\hline Alaria & & & & & 151 \\
\hline
\end{tabular}

a Average of two reported values.

bAverage of 10 kinds of kelp analyzed.

cAverage of three sample sites.

humid conditions, in which moisture might condense to concentrate water soluble iodine from the seaweed.

Additional factors known to affect iodine content of seaweed are season, salinity of the water, and depth of the seaweed, coldness of the water, distance from the equator, postharvest storage conditions, and possibly other factors (32).

Other factors that affect the iodine content of seaweed include the part of the seaweed used. The stipe (stalk), although generally regarded as inedible, could be included in specimens harvested for health food supplements. In our study, the meristematic tissue at the base of the blade had the highest iodine content. Harvesting regulations in places such as Maine require leaving the base and at least 16 inches of seaweed, including the holdfast, stipe, and first few inches of the blade, which would include the meristematic tissue, on the rock. If harvesters did this, consumers would be protected from the high iodine containing meristematic tissue. However, harvesters do not routinely follow these guidelines either in the United States or internationally (33).

Food preparation and cooking methods are other factors in determining final iodine content of foods. Iodine in seaweed is highly water-soluble. One study of the effects of cooking on kelp reported that after 15 minutes of boiling, $99 \%$ of the seaweed iodine could be found in the cooking water (34). Although not specifically related to seaweed iodine, cooking loss of iodine from iodized salt has been studied. Goindi et al. (35) reported that the method of cooking was important in iodine loss, with losses ranging from $6 \%$ when roasted, to $20 \%$ when steamed or deep fried, to $27 \%$ when shallow fried, to $37 \%-82 \%$ with boiling (36). Although the previous values are for iodine in other foods, it is likely that cooked seaweed would be subject to similar rates of loss.

A meal is never made from only seaweed. Seaweed, when eaten in a meal with other foods with goitrogenic potential, such as cassava, Brassica (broccoli, cabbage, cauliflower, bok choy, etc.) and soy, may mitigate the effect of the high iodine in the seaweed.
The activity level of the person eating the seaweed has also been reported to be significant in terms of assessing exposure to seaweed iodine (37). In a study of Japanese male university students, iodine losses in sweat during athletic training were high, suggesting that exercise in hot humid climates could increase iodine daily requirements.

Although exposure to high concentrations of iodine will transiently decrease thyroid hormone synthesis for approximately 24 hours (acute Wolff-Chaikoff effect [38]), continued exposure to excess iodine results in a decrease in the iodide concentrating ability of the thyroid by decreasing the thyroid sodium iodide symporter (NIS), permitting normal thyroid hormone synthesis to resume $(38,39)$. However, some individuals do not escape or adapt to the transient decrease in iodine-induced thyroid hormone synthesis (i.e., those with autoimmune thyroid disease [Hashimoto's thyroiditis]), and continued excess iodine ingestion may induce hypothyroiditis (40). Thus, excess ingestion of seaweeds could, in susceptible subjects, induce hypothyroidism and, far less commonly in the United States, hyperthyroidism. Episodic dietary exposure to high-iodine-containing foods could pose health risks for iodine sensitive patrons. For example, the iodine content of nori, the flat sheets of seaweed used to make sushi, contain trivial amounts of iodine $(16 \mu \mathrm{g} / \mathrm{g})$, but a bowl of miso soup made with a kelp flavored stock, even without the presence of seaweed in the final soup, could contain more than $1000 \mu \mathrm{g}$ of iodine. These sources of natural variation in iodine content contribute to the confusion in describing a particular species as "safe" for iodine sensitive individuals.

Seaweed iodine presents an interesting study in how people in Japan and Korea, with habitual exposure to seaweedcontaining diets could be relatively immune to any effects of high iodine intake, but a single seaweed rich Japanese meal could present health risks to iodine sensitive unhabituated diners in low-iodine consuming countries. A greater awareness of the variability of iodine content of seaweeds will help in defining high-risk foods for sensitive individuals. 
The observation of Paracelsus (1493-1541), the founder of toxicology, "All substances are poisons; there is none which is not a poison. The right dose differentiates a poison and a remedy" (41), may need to be amended for iodine in seaweed. The safe dose of seaweed may depend on the kind of seaweed, but also the storage conditions, cooking methods, the climate where the person resides, the amount of physical exercise a person does, the presence of goitrogenic foods eaten with the meal, and the frequency of seaweed consumption.

\section{Acknowledgments}

Support for this study was provided by the Susan G. Komen Breast Cancer Foundation Grant 9735 and the U.S. Army Medical Research and Materiel Command under DAMD 17-98-1-8207.

\section{References}

1. Rosenfeld L 2000 Discovery and early uses of iodine. J Chemi Educ 77:984-987.

2. Chapman VJ 1970 Seaweeds and Their Uses, 2nd ed. Methuen \& Co. Ltd, London, pp 304.

3. Teas J, Harbison ML, Gelman RS 1984 Dietary seaweed (Laminaria) and mammary carcinogenesis in rats. Cancer

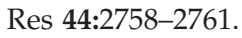

4. Yamamoto I, Maruyama H, Moriguchi M 1987 The effect of dietary seaweeds on 7,12-dimethyl-benz[a]anthracene-induced mammary tumorigenesis in rats. Cancer Lett 35:109118.

5. Maruyama H, Watanabe K, Yamamoto I 1991 Effect of dietary kelp on lipid peroxidation and glutathione peroxidase activity in livers of rats given breast carcinogen DMBA. Nutr Cancer 15:221-228.

6. Funahashi H, Imai T, Tanaka $Y$, Tsukamura $K$, Hayakawa Y, Kikumori T, Mase T, Itoh T, Nishikawa M, Hayashi H, Shibata A, Hibi Y, Takahashi M, Narita T 1999 Wakame seaweed suppresses the proliferation of 7,12-dimethylbenz(a)anthracene-induced mammary tumors in rats. Jpn J Cancer Res 90:922-927.

7. Funahashi $H$, Imai $T$, Mase T, Sekiya M, Yokoi K, Hayashi H, Shibata A, Hayashi T, Nishikawa M, Suda N, Hibi Y, Mizuno Y, Tsukamura K, Hayakawa A, Tanuma S 2001 Seaweed prevents breast cancer? Jpn J Cancer Res 92:438487.

8. Guiry MD 2003 What are algae? Seaweed Site ( National University of Galway, March 2, 2004 (Last accessed August 26, 2004).

9. Rosen J, Dillehay TD 1997 Modeling ancient plant procurement and use at Monte Verde. In: TD D (ed) Monte Verde A Late Pleistocene Settlement in Chile, Vol 2. The Archaeological Context and Interpretation, Vol. 2. Smithsonian Institution Press, Washington, D.C., pp. 331-350.

10. Ugent D, Tindall DR 1997 Sargassum: An edible seaweed. In: Dillehay TD (ed) Monte Verde A Late Pleistocene Settlement in Chile. Vol 2. The Archaeological Context and Interpretation, vol. 2. Smithsonian Institution Press, Washington, D.C., pp. 911-914.

11. Arasaki S, Arasaki T 1983 Vegetables from the Sea. Japan Publications Inc., Tokyo.

12. Misra A, Sinha R 1979 Algae as drug plants in India. In: Hoppe HA, Levring T, Tanaka Y (eds) Marine Algae in Pharmaceutical Science. Walter de Gruyter, Berlin, pp. 237-242.
13. Hoppe HA 1979 Marine algae and their products and constitutents in pharmacy. In: HA Hoppe TL, Y Tanaka (ed) Marine Algae in Pharmaceutical Science. Walter de Gruyter, New York.

14. Loeser AA 1956 Hormones and breast cancer. Lancet ii:961.

15. Schwimmer M, Schwimmer D 1955 The Role of Algae and Plankton in Medicine. Grune \& Stratton, New York.

16. Watts J 2001 Seaweed dries up in Japan. The Guardian, Thursday February 8, 2001 ed. www.guardian.co.uk/Print/ 0,3858,4133519,00.html (Last accessed March 2, 2004).

17. Ikeda J, Kawamoto N, Morii H, Murakami T 2001 A system of health education using dietary assessment. Nippon Koshu Eisei Zasshi 48:28-37.

18. INTAGE Market Report 2001 On the dining table in JapanJapanese housewives breakfast trends-Menu survey in the Keihanshin area, April (1) ed., March 2, 2004. www.intage. co.jp/express/01_04/market/index2.html (Last accessed August 26, 2004).

19. Katsura E, Nakamichi R 1960 The iodine intake of Japanese. J Jpn Soc Food Nutr 12:345-347.

20. Toyokawa H 1978 Nutritional status in Japan from the viewpoint of numerical ecology. Soc Sci Med 12:517-524.

21. Matsuzaki S, Iwamura K 1981 Application of seaweeds to human nutrition and medicine. In: von Horst Noelle H (ed) Nahrung aus dem Meer; Food from the Sea. Springer-Verlag, New York, pp. 162-184.

22. Fisheries Information Newsletter \#95 SotPC 2000 SEAWEED'S NUTRITIONAL VALUE, October-December ed. www.spc.int/coastfish/News/Fish_News/95/NIAR_9. htm (Last accessed March 2 2004).

23. Abbott IA 1978 The uses of seaweed as food in Hawaii. Economic Botany 32:409-412.

24. Schonfeld-Leber B 1979 Marine algae as human food in Hawaii, with notes on other Polynesian islands. Ecol Food Nutr 8:47-59.

25. Sloan AE 2003 What, when, and where Americans Eat: 2003. Food Technol 57:48-66.

26. Benotti J, Benotti N, Pino S, Gardyna H 1965 Determination of total iodine in urine, stool, diets, and tissue. Clin Chem 11:932-936.

27. Hou X, Chai C, Qian Q, Yan X, Fran X 1997 Determination of chemical species of iodine in some seaweeds (I). Sci Total Environ 204:215-221.

28. Meguro H, Abe T, Ogasawara T, Tuzimura K 1967 Analytical studies of iodine in food substances Part I. Chemical form of iodine in edible marine algae. Agr Biol Chem 31:999-1002.

29. Marchal P, Lognone V, Fuselier M, Bonabeze E, Brault D, Barwell C, Blondel JM, Franc M, Ninane L, Schwartz D, Menager M, Delange F, Aquaron R 2000 8th World Salt Symposium. In: Geertman RM (ed) Iodized Salt for Sustaining IDD Elimination, Vol. 2. Elsevier Science Proceedings, The Hague, The Netherlands, pp. 1015-1020.

30. Aquaron R, Delange F, Marchal P, Lognone V, Ninane L 2002 Bioavailability of seaweed iodine in human beings. Cell Mol Biol 48:563-560.

31. Lee SM, Lewis J, Buss DH, Holcombe GD, R LP 1994 Iodine in British foods and diets. Br J Nutr 72:435-446.

32. Kravtsova Y, Saenko GN 1979 Biological aspects of iodine behavior during interaction of algae with seawater. In: EV K (ed) Vaimodeistvie Vodoi Zhivym Veshchestvom Tr. Mezhdunar. Simp 1975, Vol. Publ. 1, Moscow, pp. 146-152.

33. Crawford $S 2001$ Rockweed Habitat at Risk from Commercial Harvesting Maine Audubon Society. www.maineaudubon. org/conservation/habitat/rockweed.html (Last accessed March 2, 2004). 
34. Ishizuki Y, Yamauchi K, Miura Y 1989 Transient thyrotoxicosis induced by Japanese kombu. Folia Endocrinol 65:91-98.

35. Goindi G, Karmarkar MG, Kapil U, Jagannathan J 1995 Estimation of losses of iodine during different cooking procedures. Asia Pacific J Clin Nutr 4:225-227.

36. Expert Group on Vitamins and Minerals Secretariat FSAU 2003 Review of Iodine. www.foodstandards.gov.uk/multimedia/pdfs/evm0006p.pdf (Last accessed March 2, 2004).

37. Suzuki M, Tamura T 1985 Iodine intake of Japanese male university students: urinary iodine excretion of sedentary and physically active students and sweat iodine excretion during exercise. J Nutr Sci Vitaminol (Tokyo) 31:409-415.

38. Wolff J, Chaikoff IL 1948 The inhibitory action of iodide upon organic binding of iodine by the normal thyroid gland. J Biol Chem 172:855-856.

39. Eng PH, Cardona GR, Fang SL, Previti M, Alex S, Carrasco N, Chin WW, Braverman LE 1999 Escape from the Acute Wolff-Chaikoff effect is associated with a decrease in thyroid sodium/iodide symporter messenger ribonucleic acid and protein. Endocrinology 140:3404-3410.

40. Braverman LE, Ingbar SH, Vagenakis AG, Adams L, Maloof F 1971 Enhanced susceptibility to iodine myxedema in pa- tients with Hashimoto's disease. I Clin Endocrinol Metab 32:515-521.

41. Casarett LJ, Doull J 1975 Toxicology The Basic Science of Poisons. Macmillan Publishing Co., Inc, New York.

42. Madlener JC 1977 The Sea Vegetable Book. Clarkson N. Potter, Inc., New York.

43. Hou X, Yan X 1998 Study on the concentration and seasonal variation of inorganic elements in 35 species of marine algae. Sci Total Environ 222:141-156.

44. van Netten C, Hoption Cann SA, Morley DR, van Netten JP 2000 Elemental and radioactive analysis of commercially available seaweed. Sci Total Environ 255:169-175.

Address reprint requests to: Lewis E. Braverman, M.D. Section of Endocrinology, Diabetes and Nutrition Department of Medicine Boston University School of Medicine 88 East Newton Street Evans 201 Boston, MA 02118

E-mail: lewis.braverman@bmc.org 